\title{
Japanese MNCs Investment Objectives and Subsidiary Performance
}

\author{
Norhidayah Mohamad ${ }^{1,2} \&$ Yasuo Hoshino ${ }^{1,3,4}$ \\ ${ }^{1}$ Graduate School of Business Administration, Aichi University, Japan \\ ${ }^{2}$ Faculty of Technology Management \& Technopreneurship, Universiti Teknikal Malaysia Melaka, Japan \\ ${ }^{3}$ Graduate School of Accounting, Aichi University, Japan \\ ${ }^{4}$ Institutes of Policy and Planning Sciences, University of Tsukuba, Japan \\ Correspondence: Norhidayah Mohamad, Graduate School of Business Administration, Aichi University, 2-10-31 \\ Tsutsui Higashi-ku Nagoya, 461-8641, Japan. Tel: 81-906-520-6522. E-mail: norhidayah@utem.edu.my
}

Received: July 27, 2012 Accepted: September 17, 2012 Online Published: October 1, 2012

doi:10.5539/ijbm.v7n19p132 URL: http://dx.doi.org/10.5539/ijbm.v7n19p132

\begin{abstract}
This study explores the Japanese MNCs investment objectives and their subsidiary's performance in host-county. We found five main investment objectives by Japanese MNCs generally for establishing overseas or product network followed by obtain the local market, establish overseas distribution, information gathering and cheap labor cost. China in East Asia region indicates the highest number of Japanese MNCs outward FDI followed by Southeast Asia region (Singapore, Thailand, and Malaysia) in year 2003 and 2009. The high number of Japanese MNCs in Asia may be influence by bilateral and regional approaches to take advantage of Free Trade Agreement (FTA). Our empirical results also shows that Japanese investment in Asia region more prefer to choose 'obtain local market' in the early stage of entering to host country and revise to new investment objective after certain period of time to remain the firm's profitability.
\end{abstract}

Keywords: Foreign Direct Investment (FDI), investment objectives, financial ratio, subsidiary's performance

\section{Introduction}

Going abroad through Foreign Direct Investment (FDI) is one of the strategies for sustaining business performance and survival. FDI and Multinational Corporation's (MNCs) obvious importance in world economy, has created much interest amongst scholars. FDI contributes to the economic growth of host countries, as it brings benefits such as financial resources for investment, technologies, and know-how that can be considered as important factors for economic growth (Anderson, et al., 2000). FDI, interconnected with MNCs, has already become an increasingly vital source for many developing countries to obtain international capital and advanced technology. Because of the benefits of FDI, policy makers in developing countries have formulated various strategies to attract FDI in their country (Urata, et al., 2000).

Moreover, Japan's outflows of Foreign Direct Investment (FDI) increased dramatically in the 1990s; and at that point, Japan became the world's largest overseas direct investor (Froot, et al., 1991). In 2009, Japan was the second largest FDI in the US economy, with about \$259.6 billion in investments (Jackson, 2012). Concerning this, Japanese FDI captured the interest of many researchers to understand the characteristic of the world's largest investor. Figure 1 shows the trend of Japanese FDI from 2000 to 2010. Japanese FDI outflow fell sharply from $\$ 130,801$ to $\$ 74,650$ million in 2009 , on their overseas investments in 2008 . This decrease mirrors a slowdown in global flows (Jackson, 2012). 


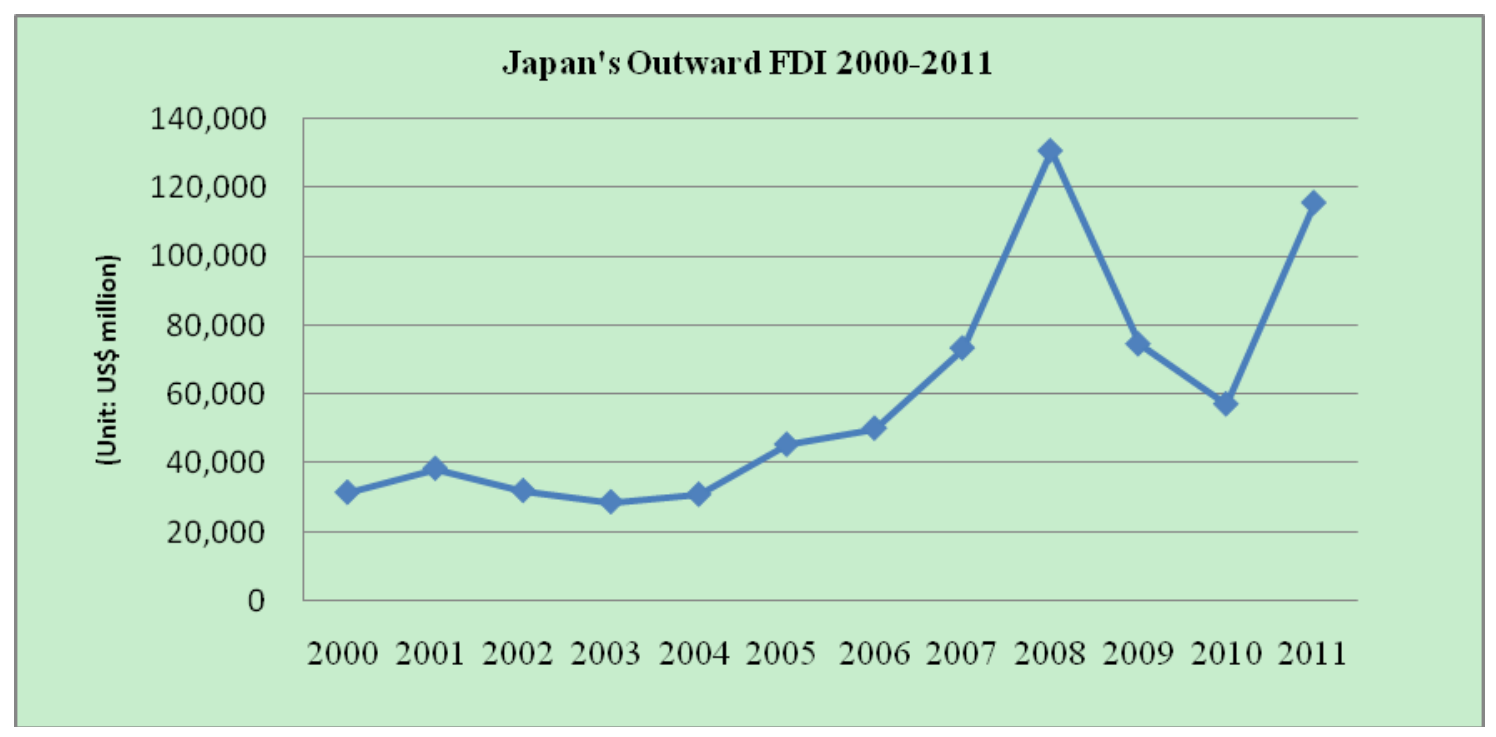

Source: Japanese Trade and Investment Statistics

Figure 1. Japan's outward FDI between 2000 and 2011

Various past researches on FDI identified the determinant factors of FDI inflow in developed and developing countries. Each country has different FDI determinant factors. Although the findings from previous studies varied, it is generally considered that the availability of cheap labour, market size, economic growth, host government policies, and sufficient infrastructures, were the main determinants of FDI (Saayman \& Snyman, 2005; Seetanah \& Rojid, 2011; Urata \& Kawai, 2000; Cheng \& Kwan, 2000).

Despite the various past studies on FDI and MNCs, research on Japanese MNCs FDI and their subsidiary performances in host countries is still in its early stage. Japanese MNCs have been essential FDIs in various countries, such as the United States, China, Malaysia, Thailand, Vietnam, and India. Therefore, this research will investigate Japanese MNCs investment objectives and the impact on their subsidiary performance, in order to obtain a better understanding of this issue.

\section{Literature Review}

\subsection{Theoretical Background}

A number of scholars have analysed the motives for international production using the transaction cost paradigm (Buckley \& Casson, 1976; Rugman, 1987). The transaction cost model offers powerful insights into the evolution of MNCs. The concept of cost minimization explains the motives for the location of FDI, which implies that a company will choose the lowest cost location for its production activities abroad. Research by Nicholas (1987) found that transaction cost factors were the important determinants of pre-1939 British manufacturing multinational's decision to invest in subsidiaries. Firms were expected to choose to enter a foreign market, only if it offered a high risk adjusted return on their investment. Therefore, transactional cost theory is an appropriate methodology for modelling dynamic growth.

Research by Dunnings (1990, 1988, and 1993), not only mentioned ownership advantage, but also included locational specific variables and the international production in eclectic paradigm that explained the FDI movement into a broad framework. This eclectic paradigm provides the most conclusive theoretical background to explain why FDI takes place. The OLI paradigm holds three kinds of advantages that shape the determination of entering a foreign market, namely Ownership, Location, and Internalization (Dunning, 2000).

Ownership advantages, refers to the possession of superior intangible and tangible assets (asset power) and skills, such as MNCs experience, firm size, and the ability to develop product differentiation. Moreover, these special advantages are specific to the investing firm and they are related to the extent to which it possesses a set of internal factors or resources and capabilities that its competitors lack. The second sub-paradigm of the OLI tripod offers a framework for evaluating alternative ways in which firms may organize the creation and exploitation of their core competencies; given the location attractions of different countries or regions. Location advantages arise from the favourable conditions possessed by the countries receiving FDI. These advantages are 
commonly associated to economical, technological, infrastructure, political, legal, social, and cultural factors, in the host countries. Finally, Internationalization advantages arise from the existence of market imperfections and the different transactional costs associated with the different ways of accessing international markets, such as exports, contracts, or FDI. These internalizing foreign activities can benefit from avoiding the dissipation of knowledge, preventing deterioration in the quality of products, and eliminating the costs of writing and enforcing contracts.

According to Galan, González-Benito \& Zuñga-Vincente (2007), the possession of such ownership specific and internalization advantages, which are a necessary condition for achieving a better international competitive position, is not enough for ensuring the potential success of investment decisions in foreign countries. Location factors should be considered as the basic determinants to define the degree of attraction of a group of host countries; with respect to the investment decision carried out by MNCs. The increasing importance of location factors can affect the global competitiveness of firms, and hence, determine their chances of future survival.

The significant effects of FDI help to explain why there is currently increased competition amongst governments of both Developed Countries (DC) and Less Developed Countries (LDC) to attract such investment. Therefore, the governments of host countries believe that attracting FDI becomes a strategy to enhance the level of economic development. It is crucial to understand the relevant for and against factors for the location decisions of Japanese MNCs in each potential group of host countries attracting FDI. Research by Galan, González-Benito \& Zuñga-Vincente (2007) explored this important issue using the Investment Development Path (IDP) paradigm that was introduced by Dunning, (2000); and Narula \& Dunning, (2000).

Using this approach helps to decide upon the main reasons and objectives, and hence, the different location factors that can decisively determine the choice of one country or another, as the final destination for FDI, made by Japanese MNCs. As stated by Narula, Dunning (2000) \& Narula (1996), the proponents of this dynamic and integrative approach, posit that the kind of MNCs that any country is capable of attracting or creating over time, depends on its international investment position; and hence, on its level of economic development. Five stages of evolution were used to examine this economic development (see Figure 2). 


\begin{tabular}{|c|c|}
\hline Stage 1 & Stage 2 \\
\hline $\begin{array}{l}\text { - } \quad \text { Level of FDI } \\
\text { countries } \\
\text { with little } \\
\text { or inward } \\
\text { FDI and no } \\
\text { outward } \\
\text { FDI } \\
\text { - Type of L } \\
\text { advantages: } \\
\text { Countries } \\
\text { with limited } \\
\text { L } \\
\text { advantages. } \\
\text { Have not } \\
\text { fully } \\
\text { developed } \\
\text { created-ass } \\
\text { et L } \\
\text { advantages } \\
\text { Motive of FDI } \\
\text { received } \\
\text { primarily } \\
\text { natural } \\
\text { resources-s } \\
\text { eeking and } \\
\text { market-see } \\
\text { king }\end{array}$ & $\begin{array}{l}\text { Level of FDI } \\
\text { countries } \\
\text { with } \\
\text { growing } \\
\text { inward FDI } \\
\text { and little } \\
\text { outward } \\
\text { FDI } \\
\text { Type of L } \\
\text { advantages: } \\
\text { Countries } \\
\text { generic L } \\
\text { advantages } \\
\text {. Have not } \\
\text { fully } \\
\text { developed } \\
\text { created-ass } \\
\text { et L } \\
\text { advantages } \\
\text { but some } \\
\text { of them } \\
\text { begin to } \\
\text { invest in } \\
\text { them } \\
\text { Motive of FDI } \\
\text { received } \\
\text { primarily } \\
\text { natural } \\
\text { resources } \\
\text { seeking } \\
\text { and } \\
\text { market-see } \\
\text { king }\end{array}$ \\
\hline
\end{tabular}

Developing countries: Latin America, North America \& Asian countries

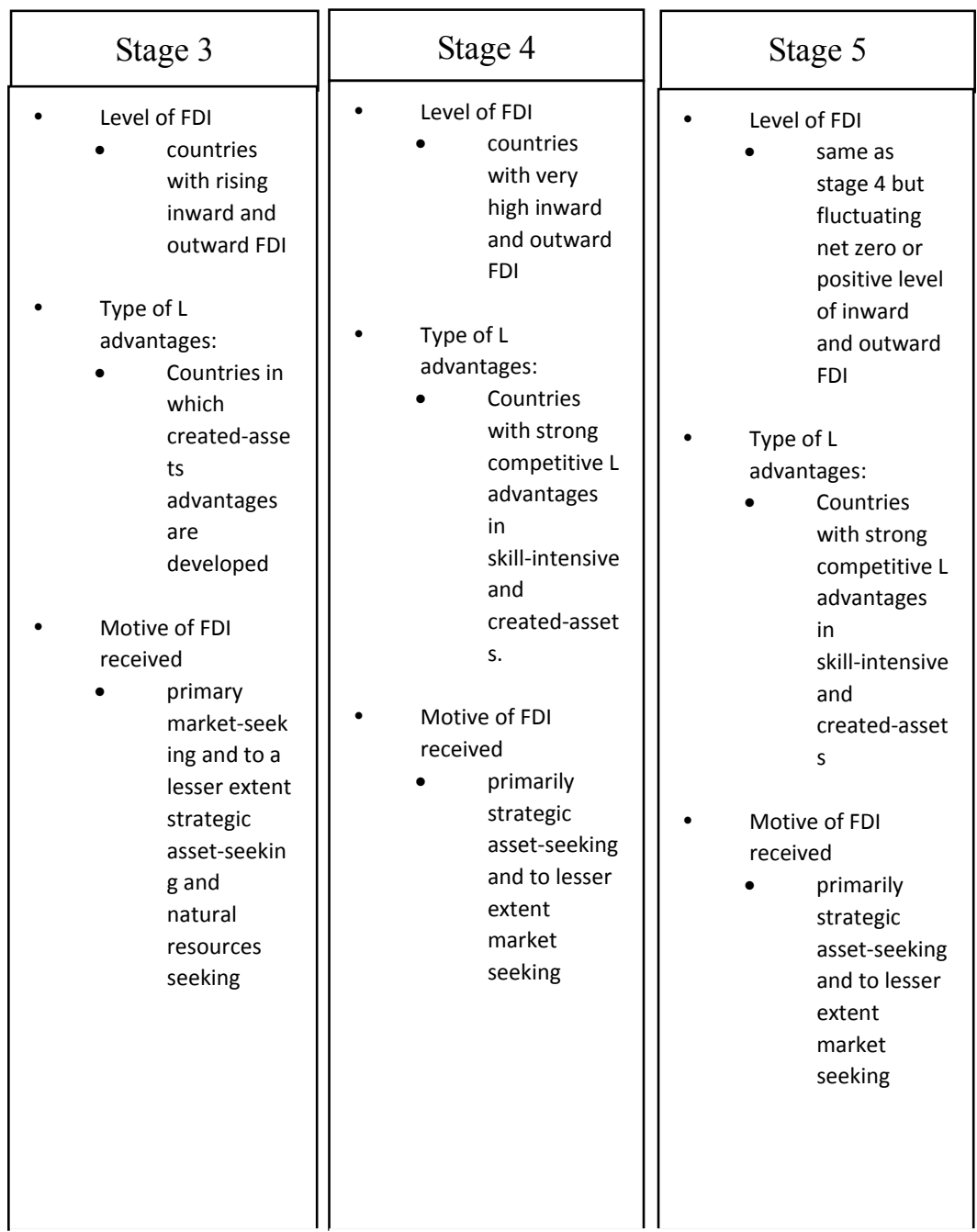

Newly Industrialized countries: Latin America, Eastern Europe \& South East Asian countries
Developed Countries: United States, Japan, EU countries, \& other OECD countries

Source: Galan, González-Benito, \& Zuñga-Vincente, (2007) and Narula \& Dunning, (2000)

Figure 2. Characteristics of the IDP

The first stage consisted of wealthy industrialized countries, or DCs (that over the past two decades had experienced a convergence of their income levels, consumption patterns, and technological resources and capabilities). Figure 2 shows the final two stages that located these DCs. The second group was comprised of Newly Industrialized Countries (NICs), which were catching up and converging with the DCs during the third stage of the IDP paradigm. The third IDP category was made-up of a large number of LDCs that were far from converging with DCs and NICs. LDCs are in the least developed stages of the IDP (i.e., Stage 1 and 2). It would be easy to predict the kind of location factor, if the positions of the FDI and host countries in the IDP were known.

\subsection{Conceptual Framework and Hypotheses}

The proponents of the IDP approach acknowledge that there are three main objectives for MNCs to carry out FDI, which are to seek natural resources, new markets, and strategic assets (Dunning, 1993). As illustrated in Figure 2, there are significant differences between LDCs and DCs in four perspectives (i.e., the level of FDI, the type of basic location advantages, the reason why FDI was received, and the most relevant locational factors for attracting FDI). Previous research by Galan, González-Benito \& Zuñga-Vincente (2007), stated that DCs 
specific advantages are strongly linked to created assets; while LDC's natural resource and market seeking, become the main objectives. Figure 3 provides the integrative conceptual framework for the subsequent development of the hypothesis. As the figure shows, one of the most important decisions currently faced by an FDI inflow country is the choice of the potential group of host countries for locating their cross-border investments. Evidently, the choice of one or another group of host countries would be driven by the main investment objectives of the Japanese MNC's parent company, from the host country. Galan, González-Benito, \& Zuñga-Vincente (2007) recognized that the MNC's parent company motivation was to eventually choose either or both groups of host countries, depends on the specific location factors available in them.

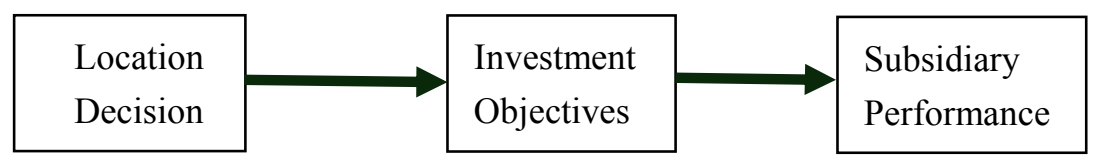

Figure 3. Integrative conceptual framework

\subsection{The Determinants of FDI}

The issue of FDI determinants was first addressed by Ohlin in 1933. He mentioned that FDI was mainly motivated by high profitability in growing markets, with the possibility of finance and low interest rates. Meanwhile, according to Snyman \& Saayman (2009), perception and infrastructure, government and policy, economy, competitiveness and nature, were the key factors influencing the FDI in South Africa. In Mauritius, trade openness, wages, and the quality of labour in the host country, were the most instrumental factors for FDI. Market size relatively had a lesser impact on FDI; which was probably related to a small population size (Seetanah, et al., 2011).

Other previous researches by Urata and Kawai (2000) stated that both supply side and demand side factors are important in the recipient countries for attracting the FDI by Japanese MNCs. Supply side factors include the abundance of low-wage labour, the availability of a good infrastructure, and a good governance of the host. However, the demand side factors consist of a sizeable local market. The supply and demand concept can be used to investigate the motives of Japanese MNCs FDI in other countries. Labour costs factor appear particularly important determinants by various past research where foreign companies prefer to investing in host countries which enable to capitalise their inexpensive labour. (Asiedu, 2006; Tahir \& Larimo, 2006; Bandelj, 2002; Buckley \& Casson, 1998; Dunning, 1988; Saayman \& Snyman, 2005; Cheng \& Kwan, 2000; Resmini, 2000; Wheeler \& Mody, 1992. In addition, studies on location determinants of Japanese manufacturing FDI by Kinoshita (1998) in seven Asian countries found that labour cost and infrastructure encourage small firms to invest in certain country, while market size and strategic consideration are most important determinants for locational decisions for large firms.

Good quality of infrastructure is more preferable determinant by the foreign investors followed by changes in real bilateral exchange rates and expanding domestic market; and (Wheeler \& Mody, 1992; Nakamura \& Oyama, 1998). The big domestic market with high quality of labour and political leadership in European unification has make France as the attractiveness country for Japanese FDI (Sazanami, 1992). Foreign investors prefer large markets with high growth prospects to ensure the vast return on their investment. On the other hand, local government and political stability also play a role in attracting foreign investments since the stage of the transition process is under the policy makers' control (Resmini, 2000; Sazanami, 1992; Asiedu, 2006). These local government policies comprise direct impact on long-term economic growth for the host country. Moreover, Argawal (1994) found that political conditions pose operating risk for a foreign investor. This operating risk helps the investor to determine the form of the entry mode.

The determinants of FDI include the analysis of the conditions for host countries to attract foreign investment. These conditions are also known as the locational determinants of FDI. Moreover, this taxonomy for locational determinants is similar to the research on motivations for FDI (Driffield \& Love, 2007), Drivers of FDI (Ok, 2004), and Motives for FDI (Bitzenis et al, 2007). All of these studies are particularly relevant to the developed and developing countries that are striving for foreign investments in the host county. This is because FDI brings many advantages, such as foreign capital and advanced technologies. Table 1 provides a detailed list of the FDI determinants considered by several empirical studies, which have examined the influence on location decisions of MNC's parent companies in both DCs and LDCs. 
Table 1. Determinants of FDI (selected studies)

\begin{tabular}{|c|c|}
\hline Factors & Authors \\
\hline $\begin{array}{c}\text { Market size } \\
\text { (Micro economic) }\end{array}$ & $\begin{array}{l}\text { Tahir \& Larimo, (2006); Kobrin, (1976); Davidson, (1980); Eicher \& Kang, (2005); } \\
\text { Saayman \& Snyman, (2005); Cheng \& Kwan, (2000); Resmini, (2000); Urata \& Kawai, } \\
\text { (2000); Sazanami, (1992); Wheeler \& Mody (1992); Asiedu (2006); Kinoshita (1998); } \\
\text { Nakamura \& Oyama (1998) }\end{array}$ \\
\hline Economic growth & $\begin{array}{l}\text { Tahir \& Larimo, (2006); Kobrin, (1976); Davidson, (1980); Saayman \& Snyman, (2005); } \\
\text { Loree \& Guisinger, (1995); Dar et al., (2004); Asiedu, (2006) }\end{array}$ \\
\hline $\begin{array}{l}\text { Labour supply } \\
\quad / \text { costs }\end{array}$ & $\begin{array}{l}\text { Buckley \& Casson, (1985); Dunning, (1988); Eicher \& Kang, (2005); Saayman \& Snyman, } \\
\text { (2005); Cheng \& Kwan, (2000); Resmini, (2000); Urata \& Kawai, (2000); Loree \& } \\
\text { Guisinger, (1995); Kinoshita, (1998); Wheeler \& Mody (1992); Asiedu (2006); Tahir \& } \\
\text { Larimo (2006) }\end{array}$ \\
\hline Labour quality & Sazanami, (1992); Bandelj (2002) \\
\hline $\begin{array}{r}\text { Political } \\
\text { enviror }\end{array}$ & $\begin{array}{l}\text { Agarwal, (1994); Anderson \& Gatignon, (1986); Sazanami, (1992); Wheeler \& Mody } \\
\text { (1992); Kobrin (1976); (Asiedu (2006) }\end{array}$ \\
\hline $\begin{array}{l}\text { Raw material/ } \\
\text { Natural resources }\end{array}$ & Buckley \& Casson, (1985); Dunning, (1988); Asiedu, (2006) \\
\hline $\begin{array}{l}\text { Host government } \\
\text { policies }\end{array}$ & $\begin{array}{l}\text { Davidson \& McFetridge, (1998); Eicher \& Kang, (2005); Saayman \& Snyman, (2005); } \\
\text { Cheng \& Kwan, (2000); Resmini, (2000); Urata \& Kawai, (2000); Sazanami, (1992); } \\
\text { Kinoshita, (1998) }\end{array}$ \\
\hline $\begin{array}{l}\text { Tariffs \& trade } \\
\quad \text { barriers }\end{array}$ & $\begin{array}{l}\text { Eicher \& Kang, (2005); Saayman \& Snyman, (2005); Cheng \& Kwan, (2000); Nakamura } \\
\text { \& Oyama, (1998) }\end{array}$ \\
\hline $\begin{array}{l}\text { Openness \& export } \\
\text { (Macroeconomic) }\end{array}$ & $\begin{array}{l}\text { Bandelj, (2002); Cheng \& Kwan, (2000); Resmini, (2000); Urata \& Kawai, (2000); Bhinda } \\
\text { et al., (1999); Wheeler \& Mody, (1992); Loree \& Guisinger, (1995); Asiedu, (2006); } \\
\text { Kinoshita (1998) }\end{array}$ \\
\hline Exchange rate & $\begin{array}{l}\text { Bandelj, (2002); Cheng \& Kwan, (2000); Resmini, (2000); Urata \& Kawai, (2000); Bhinda } \\
\text { et al., (1999); Nakamura \& Oyama, (1998); Dar et al., (2004) }\end{array}$ \\
\hline Inflation rate & $\begin{array}{l}\text { Bandelj, (2002); Cheng \& Kwan, (2000); Urata \& Kawai, (2000); Bhinda et al., (1999); } \\
\text { Asiedu, (2006) }\end{array}$ \\
\hline Inflation rate & $\begin{array}{l}\text { Bandelj, (2002); Cheng \& Kwan, (2000); Urata \& Kawai, (2000); Bhinda et al., (1999); } \\
\text { Asiedu, (2006) }\end{array}$ \\
\hline Budget deficits & Bandelj, (2002); Cheng \& Kwan, (2000); Urata \& Kawai, (2000); Bhinda et al., (1999) \\
\hline Investment & Bandelj, (2002), Cheng \& Kwan, (2000); Urata \& Kawai, (2000); Bhinda et al., (1999) \\
\hline $\begin{array}{l}\text { Infrastructure/ } \\
\text { transportation/ } \\
\text { logistic }\end{array}$ & $\begin{array}{l}\text { Bandelj, (2002); Cheng \& Kwan, (2000); Urata \& Kawai, (2000); Bhinda et al., (1999); } \\
\text { Wheeler \& Mody, (1992); Kinoshita, (1998); Sazanami, (1992); Asiedu (2006) }\end{array}$ \\
\hline Political stability & $\begin{array}{l}\text { Bandelj, (2002); Cheng \& Kwan, (2000); Resmini, (2000); Urata \& Kawai, (2000); Bhinda } \\
\text { et al., (1999); Wheeler \& Mody, (1992); Asiedu, (2006) }\end{array}$ \\
\hline Location & Sazanami, (1992); Wheeler \& Mody (1992) \\
\hline
\end{tabular}

Previous literature revealed that there is widespread interest in international business research about MNCs seeking a particular host country. Relatively few studies exist on MNCs investment objective's affecting subsidiary performance in the host country. Based on this previous literature, this study aims to provide a new insight of strategic investment objectives, which have influenced business performance in the context of Japanese FDI. Based on all previous arguments, we propose the following three specific hypotheses:

- Hypothesis 1: There is a significant difference between Japanese investment objectives and location factors.

- Hypothesis 2: There is a significant difference between Japanese investment objectives and subsidiary performance.

- Hypothesis 3: There is a significant difference between Japanese location decision factors and subsidiary 
performance.

\section{Methodology}

We selected Japanese MNCs to test these hypotheses, because Japanese MNCs are a major worldwide FDI. As mentioned earlier, Japanese firms have invested abroad since the early 1980s. They have become a major supplier of capital to the world. Japanese FDI has captured the interest of many researchers as a research topic, in order to understand the characteristics of the world's largest investor.

This study examines the relationship between Japanese MNCs investment objectives and its subsidiary performance. The data analysis used the subsidiary's performance as a dependent variable, along with investment objectives that consisted of 16 items, used for the independent variables.

\subsection{Data Collection}

Entry mode and the subsidiary's performance data were derived from Tokyo Keizai Inc., Database CD-ROM series for 2003 with 3,757 cases and 2009 with 2,661 cases. The investment objectives were coded from 1 to 15 . Furthermore, the subsidiary's performance data was derived from a self-assessed performance, as surveyed by Toyo Keizai Inc., by asking the top Japanese managers in each subsidiary to assess their performance in terms of financial profitability, i.e., gain, break-even, or loss, using a three-point scale.

There are two reasons why subjective measurements are appropriate. First, subsidiaries do not disclose their performance data. Second, the three-point scale of financial performance is a better proxy for performance than the objective measure of financial profit; particularly when the parent firm adopts transfer pricing towards its foreign subsidiaries (Makino, et al., 1998).

\subsection{Sample}

The data consisted of Japanese FDI abroad for the years 2003 and 2009. In these years, only 3,757 and 2,661 cases were available, with investment objectives and performance data, respectively. Table 2 shows the number of Japanese MNCs subsidiaries cluster, by subsidiary performance.

Table 2. Number of samples based on subsidiary performance in 2003 and 2009

\begin{tabular}{ccc}
\hline Performance & No. of Cases 2003 & No. of Cases 2009 \\
\hline Gain & 2112 & 1514 \\
Breakeven & 880 & 732 \\
Loss & 765 & 415 \\
Total & 3757 & 2661
\end{tabular}

Source: Toyo Keizai Inc., 2003 and 2009

\subsection{Dependent Variable}

The dependent variable is a dichotomous dummy variable, constructed based on the top Japanese manager's assessment of his or her subsidiary's financial performance. This variable will be given a value of ' 1 ' (equivalent to low performance) when the answer is 'loss' or 'breakeven' and a value of '2' (equivalent to high performance) when the answer is 'gain'. Even though categorical performance measures have limitations, there are three main arguments that support this type of measure. As quoted by Cespedes \& Hoshino (2001), the three conditions enabling this measurement are 1) where available, financial measures of performance are not directly comparable across industries and countries with different accounting systems and customs (Brown, et al., 1994). 2) Because the survey respondent is the top Japanese Manager in each subsidiary, it expected that each manager will report the subsidiary's performance from a similar reference point (Makino, et al., 1996). 3) Managers' perceptions of performance were demonstrated to correlate with objective financial measures (Geringer, et al., 1991).

\subsection{Independent Variables}

This research consists of two independent variables, namely locational factor (subsidiary region and country) and investment objectives with 15 items; as shown in Table 3. These investment objectives come from Japanese MNCs parent company's investment objectives. The 15 items were constructed from previous studies related to FDI determinants, motives, motivations, and influence. 


\section{Empirical Results}

\subsection{Descriptive Statistics of the Samples}

Table 3 shows the findings of the descriptive statistics with a number of Japanese MNCs investment objectives and subsidiary locations clustered by region. In comparing some of the descriptive statistics of the sample from Japanese MNCs, some facts are worthy of mention. In 2003, the main Japanese investment objective was to obtain a local market with more than 1,000 subsidiaries worldwide. However, in 2009, most Japanese MNCs were going abroad to establish overseas or production networks as their main investment objectives, with more than 600 cases; followed by obtaining a local market with half the number of the favoured objectives. Moreover, establishing overseas distribution and information gathering was consider as important investment objectives, since a number of cases were among the top five of more than 200 subsidiaries. Comparing Japanese investment objectives in these two years, we found that the motives of investment of establishing overseas/production network, favoured treatment by local government, and natural recourses, had slightly increased.

By looking at the subsidiary's region, the highest three regions for Japanese FDI are East Asia, Southeast Asia, and North America; with more than 300 Japanese MNCs subsidiaries located in these areas (see Table 3). Among the foreign investors in East and Southeast Asia, Japanese firms have held the important position of leading investor, in terms of FDI values. Various factors may contribute towards active Japanese investment in Asian countries. Geographical location is one factor. North America showed that half of its outflows in 1990s were Japanese FDI (Froot, et al., 1991). Northern Europe, the Middle East, and Africa were the lowest rated Japanese FDIs, with less than 20 Japanese subsidiaries operating in those areas/countries.

Table 3. Descriptive statistics

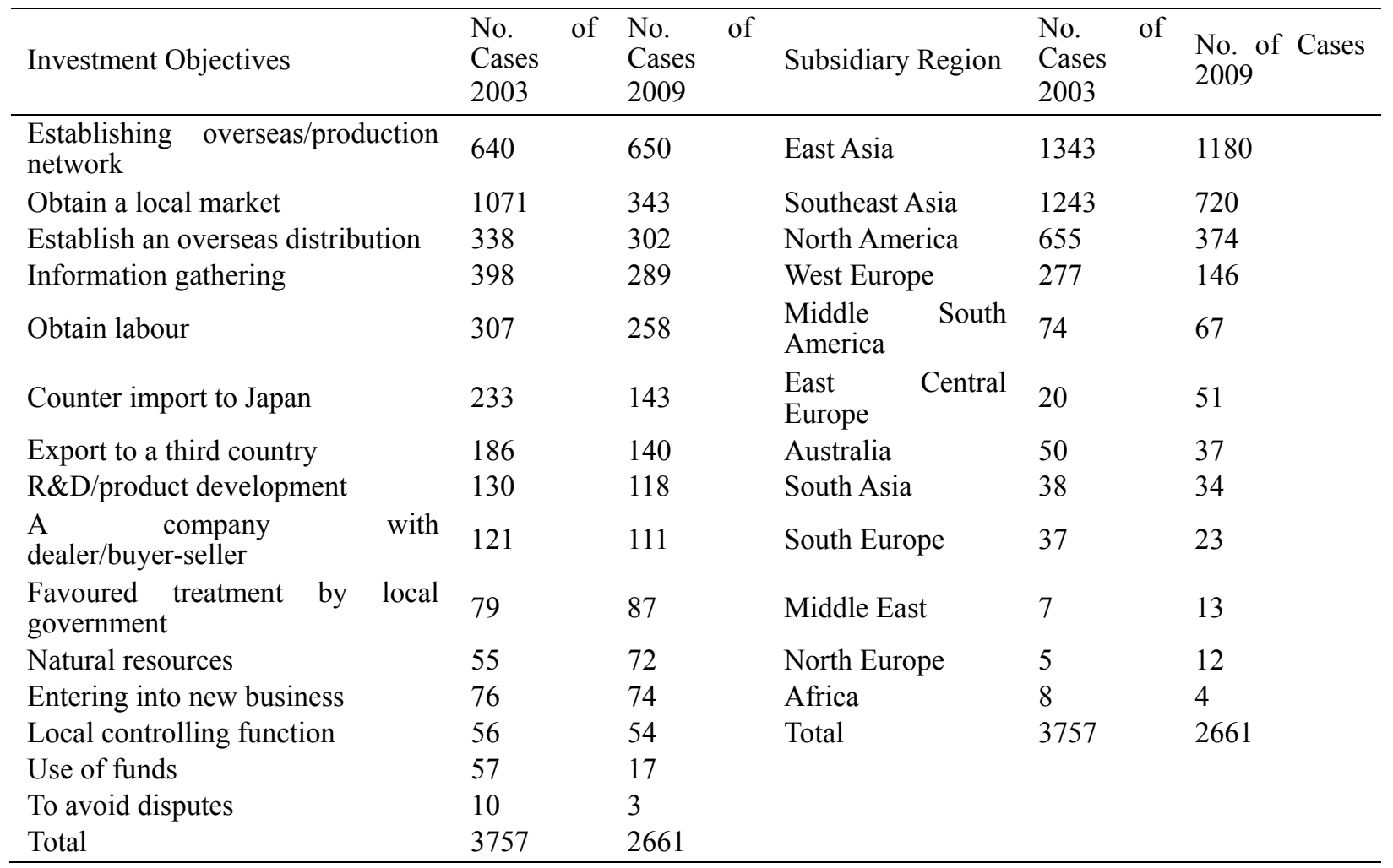

Source: Toyo Keizai Inc., 2003 and 2009

In Asian countries, China showed the highest number of Japanese FDIs in both 2003 (673 subsidiaries) and 2009 (832 subsidiaries); see Figure 4. America, with 608 subsidiaries in 2003, was shown to be the second most favourable country, followed by Thailand with 403 subsidiary companies. However, Japanese investment in America declined dramatically in 2009, with half the number of subsidiaries in 2003. This data is in line with the previous analysis of Japanese subsidiary by region, which showed that China was the most favourable country, followed by Thailand and North America. Overall, most countries indicated a high Japanese investment in 2003, which dropped in 2009; except for China. Japanese investment in China rose by more than $20 \%$ in 2009. 




Source: Toyo Keizai Inc., 2003 and 2009

Figure 4. Number of Japanese subsidiaries by country in 2003 and 2009

\subsection{The Difference between Investment Objectives, Location Factors, and Subsidiary Performance}

We conducted a Kruskal-Wallis test to analyse the effects of locational factors towards Japanese subsidiary's investment objectives. The Kruskal-Wallis results shown in Table 4 indicate that location factors significantly influenced subsidiary's investment objectives, with $p=0.000$ in 2003 and 2009. This difference exists between subsidiary countries and regions towards Japanese MNCs investment objectives. Therefore, these findings support the first hypothesis of this research, where locational factors significantly affect Japanese MNC's investment objectives.

Table 4. Kruskal-Wallis results for the location factor and subsidiary investment objectives

\begin{tabular}{ccccc}
\hline Location & Year & Chi-Square & df & Sig \\
\hline Subsidiary & 2003 & 195.19 & 14 & 0.000 \\
Country & 2009 & 125.85 & 14 & 0.000 \\
Subsidiary & 2003 & 174.80 & 14 & 0.000 \\
Region & 2009 & 118.91 & 14 & 0.000
\end{tabular}

Moreover, we also analysed the difference between Japanese investment objectives and the locational factor on Japanese MNCs subsidiary's performance. Performance was measured using a three-point scale i.e., gain, break-even, or loss. The results from the Kruskal-Wallis test showed that subsidiary performance in 2003 and 2009 differed significantly across all Japanese investment objectives and locational factors, with a $\mathrm{p}$ value of less than 0.05 . Table 5 shows that location factors, such as region and country, had a significant influence on subsidiary performance. 
Table 5. Kruskal-Wallis results for Japanese investment objectives, locational factors, and subsidiary performance

\begin{tabular}{lrrrrr}
\hline & \multicolumn{1}{c}{ Year } & \multicolumn{1}{c}{ Mean } & Chi-Square & df & \multicolumn{2}{c}{ Sig } \\
\hline Investment & 2003 & 2.36 & 35.55 & 14 & 0.001 \\
Objectives & 2009 & 2.41 & 499.99 & 14 & 0.000 \\
Location & & & & & \\
Subsidiary & 2003 & 2.36 & 98.51 & 11 & 0.000 \\
Region & 2009 & 2.41 & 49.45 & 11 & 0.000 \\
Subsidiary & 2003 & 2.36 & 213.83 & 42 & 0.000 \\
Country & 2009 & 2.41 & 140.73 & 39 & 0.000 \\
\hline
\end{tabular}

To look into the details of these differences, we ran a cross-tabulation between Japanese investment objectives and subsidiary performance. As shown in Table 6, most Japanese investment objectives for 2003 and 2009 illustrated a performance 'Gain', except for obtaining a local market objective. However, obtaining a local market was the second highest number for Japanese MNCs investment objectives. Even though previous studies showed that market size was the most determining factor for FDI, this research reveals that this factor had a breakeven performance towards Japanese MNCs subsidiaries, compared to all of the other factors in 2009.

Table 7 details subsidiary locational factors, main Japanese MNCs investment objectives, and subsidiary performances for 2003 and 2009. In 2009, most Japanese MNCs indicate a good performance compared to 2003; which had mixed subsidiary performances for several countries. In 2003, Japanese subsidiaries in the United Kingdom, France, and Australia, showed that 'obtaining a local market' (as was their main investment objective to operate in those countries), experienced a breakeven or loss performance. Moreover, Japanese investments in Turkey and Hungary, with 'obtain labour' as their main investment objective in 2003, were also not very successful with a loss performance. In addition, in 2003 and 2009, Argentina was also not very successful with their main investment objective to obtain a local market, which showed a 'loss' performance for those years. Therefore, this analysis supports the first hypothesis's second and third state, where there is a significant difference between Japanese investment objectives and locational factors towards subsidiary performance.

Table 6. Crosstab table for investment objectives and subsidiary performance

\begin{tabular}{|c|c|c|c|c|c|c|c|c|c|}
\hline \multirow{3}{*}{ Investment Objectives } & \multirow{3}{*}{ Year } & \multicolumn{6}{|c|}{ Performance } & \multirow{2}{*}{\multicolumn{2}{|c|}{ Total }} \\
\hline & & \multicolumn{2}{|l|}{ Loss } & \multicolumn{2}{|c|}{ Breakeven } & \multicolumn{2}{|l|}{ Gain } & & \\
\hline & & Count & $\%$ & Count & $\%$ & Count & $\%$ & Count & $\%$ \\
\hline \multirow{2}{*}{$\begin{array}{c}\text { Establishing an } \\
\text { overseas/production network }\end{array}$} & 2003 & 131 & $20.5 \%$ & 118 & $18.4 \%$ & 391 & $61.1 \%$ & 640 & $100 \%$ \\
\hline & 2009 & 91 & $14 \%$ & 135 & $20.8 \%$ & 424 & $65.2 \%$ & 650 & $100 \%$ \\
\hline \multirow{2}{*}{ Obtain a local market } & 2003 & 229 & $21.4 \%$ & 248 & $23.2 \%$ & 594 & $55.5 \%$ & 1071 & $100 \%$ \\
\hline & 2009 & 130 & $37.9 \%$ & 204 & $59.5 \%$ & 9 & $2.6 \%$ & 343 & $100 \%$ \\
\hline \multirow{2}{*}{ Establish overseas distribution } & 2003 & 68 & $20.1 \%$ & 83 & $24.6 \%$ & 187 & $55.3 \%$ & 338 & $100 \%$ \\
\hline & 2009 & 26 & $8.6 \%$ & 53 & $17.5 \%$ & 223 & $73.8 \%$ & 302 & $100 \%$ \\
\hline \multirow{2}{*}{ Information gathering } & 2003 & 57 & $14.3 \%$ & 122 & $30.7 \%$ & 219 & $55 \%$ & 398 & $100 \%$ \\
\hline & 2009 & 36 & $12.5 \%$ & 83 & $28.7 \%$ & 170 & $58.3 \%$ & 289 & $100 \%$ \\
\hline \multirow[b]{2}{*}{ Obtain labour } & 2003 & 67 & $21.8 \%$ & 65 & $21.2 \%$ & 175 & $57 \%$ & 307 & $100 \%$ \\
\hline & 2009 & 32 & $12.4 \%$ & 56 & $21.7 \%$ & 170 & $65.9 \%$ & 258 & $100 \%$ \\
\hline \multirow{2}{*}{ Counter import to Japan } & 2003 & 56 & $24 \%$ & 52 & $22.3 \%$ & 125 & $53.6 \%$ & 233 & $100 \%$ \\
\hline & 2009 & 14 & $9.8 \%$ & 33 & $23.1 \%$ & 96 & $67.1 \%$ & 143 & $100 \%$ \\
\hline \multirow{2}{*}{ Export to third country } & 2003 & 47 & $25.3 \%$ & 40 & $21.5 \%$ & 99 & $53.2 \%$ & 186 & $100 \%$ \\
\hline & 2009 & 20 & $14.3 \%$ & 28 & $20 \%$ & 92 & $65.7 \%$ & 140 & $100 \%$ \\
\hline
\end{tabular}




\begin{tabular}{cccccccccc}
\hline R\&D/product development & 2003 & 28 & $21.5 \%$ & 35 & $26.9 \%$ & 67 & $51.5 \%$ & 130 & $100 \%$ \\
& 2009 & 22 & $18.6 \%$ & 42 & $35.6 \%$ & 54 & $45.8 \%$ & 118 & $100 \%$ \\
A company with & 2003 & 27 & $22.3 \%$ & 29 & $24 \%$ & 65 & $53.7 \%$ & 121 & $100 \%$ \\
dealer/buyer-seller & 2009 & 9 & $8.1 \%$ & 18 & $16.2 \%$ & 84 & $75.5 \%$ & 111 & $100 \%$ \\
Favoured treatment by local & 2003 & 6 & $7.6 \%$ & 15 & $19 \%$ & 58 & $73.4 \%$ & 79 & $100 \%$ \\
government & 2009 & 12 & $13.8 \%$ & 9 & $10.3 \%$ & 66 & $75.9 \%$ & 87 & $100 \%$ \\
Natural resources & 2003 & 9 & $16.4 \%$ & 15 & $27.3 \%$ & 31 & $56.4 \%$ & 55 & $100 \%$ \\
Entering into new business & 2009 & 8 & $11.1 \%$ & 21 & $29.2 \%$ & 43 & $59.7 \%$ & 72 & $100 \%$ \\
& 2003 & 20 & $26.3 \%$ & 27 & $35.5 \%$ & 29 & $38.2 \%$ & 76 & $100 \%$ \\
Local controlling function & 2009 & 11 & $14.9 \%$ & 22 & $29.7 \%$ & 41 & $55.4 \%$ & 74 & $100 \%$ \\
& 2003 & 11 & $19.6 \%$ & 20 & $35.7 \%$ & 25 & $44.6 \%$ & 56 & $100 \%$ \\
Use of funds & 2009 & 4 & $7.4 \%$ & 22 & $40.7 \%$ & 28 & $51.9 \%$ & 54 & $100 \%$ \\
To avoid disputes & 2003 & 8 & $14 \%$ & 11 & $19.3 \%$ & 38 & $66.7 \%$ & 57 & $100 \%$ \\
& 2009 & 0 & $0 \%$ & 5 & $29.4 \%$ & 12 & $70.6 \%$ & 17 & $100 \%$ \\
& 2003 & 1 & $10 \%$ & 0 & $0 \%$ & 9 & $90 \%$ & 10 & $100 \%$ \\
\hline
\end{tabular}

Table 7. Subsidiary countries, main investment objectives, and firm performance

\begin{tabular}{|c|c|c|c|c|c|c|c|c|c|c|}
\hline \multirow[b]{2}{*}{ Location } & \multirow[b]{2}{*}{ Year } & \multirow{2}{*}{$\begin{array}{l}\text { Main Investment } \\
\text { Objectives }\end{array}$} & \multicolumn{6}{|c|}{ Performance } & \multicolumn{2}{|c|}{ Total } \\
\hline & & & $\begin{array}{l}\text { Loss } \\
\text { count }\end{array}$ & $\%$ & $\begin{array}{c}\text { Breakeve } \\
\mathrm{n} \text { count }\end{array}$ & $\%$ & $\begin{array}{l}\text { Gain } \\
\text { count }\end{array}$ & $\%$ & count & $\%$ \\
\hline \multicolumn{11}{|l|}{ East Asia } \\
\hline \multirow{2}{*}{$\begin{array}{l}\text { South } \\
\text { Korea }\end{array}$} & 2003 & Obtain a local market & 20 & $14.9 \%$ & 23 & $17.2 \%$ & 91 & $67.9 \%$ & 134 & $100 \%$ \\
\hline & 2009 & $\begin{array}{c}\text { Establishing an } \\
\text { overseas/production }\end{array}$ & 5 & $6.9 \%$ & 25 & $34.7 \%$ & 42 & $58.3 \%$ & 72 & $100 \%$ \\
\hline \multirow{2}{*}{ China } & 2003 & $\begin{array}{c}\text { Establishing } \\
\text { overseas/production }\end{array}$ & 158 & $23.5 \%$ & 117 & $17.4 \%$ & 398 & $59.1 \%$ & 673 & $100 \%$ \\
\hline & 2009 & $\begin{array}{c}\text { Establishing } \\
\text { overseas/production }\end{array}$ & 126 & $15 \%$ & 254 & $30.2 \%$ & 461 & $54.8 \%$ & 841 & $100 \%$ \\
\hline \multirow[b]{2}{*}{ Hong Kong } & 2003 & Obtain a local market & 57 & $18.7 \%$ & 78 & $25.6 \%$ & 170 & $55.7 \%$ & 305 & $100 \%$ \\
\hline & 2009 & $\begin{array}{l}\text { Establish overseas } \\
\text { distribution }\end{array}$ & 17 & $10.6 \%$ & 43 & $26.7 \%$ & 101 & $62.7 \%$ & 161 & $100 \%$ \\
\hline \multirow[b]{2}{*}{ Taiwan } & 2003 & Obtain a local market & 32 & $13.9 \%$ & 46 & $19.9 \%$ & 153 & $66.2 \%$ & 231 & $100 \%$ \\
\hline & 2009 & $\begin{array}{c}\text { Establishing } \\
\text { overseas/production }\end{array}$ & 32 & $27.8 \%$ & 27 & $23.5 \%$ & 56 & $48.7 \%$ & 115 & $100 \%$ \\
\hline \multicolumn{11}{|l|}{$\begin{array}{l}\text { Southeast } \\
\text { Asia }\end{array}$} \\
\hline \multirow{2}{*}{ Vietnam } & 2003 & Obtain labour & 15 & $21.1 \%$ & 11 & $15.5 \%$ & 45 & $63.4 \%$ & 71 & $100 \%$ \\
\hline & 2009 & Obtain labour & 16 & $24.2 \%$ & 0 & $0 \%$ & 50 & $75.8 \%$ & 66 & $100 \%$ \\
\hline \multirow[b]{2}{*}{ Thailand } & 2003 & Obtain a local market & 57 & $14.1 \%$ & 86 & $21.3 \%$ & 260 & $64.5 \%$ & 403 & $100 \%$ \\
\hline & 2009 & $\begin{array}{c}\text { Establishing } \\
\text { overseas/production }\end{array}$ & 24 & $8.7 \%$ & 60 & $21.7 \%$ & 193 & $69.7 \%$ & 277 & $100 \%$ \\
\hline \multirow[b]{2}{*}{ Singapore } & 2003 & Obtain a local market & 25 & $9.9 \%$ & 68 & $27 \%$ & 159 & $63.1 \%$ & 252 & $100 \%$ \\
\hline & 2009 & $\begin{array}{l}\text { Establish overseas } \\
\text { distribution }\end{array}$ & 5 & $4.6 \%$ & 32 & $29.4 \%$ & 72 & $66.1 \%$ & 109 & $100 \%$ \\
\hline
\end{tabular}




\begin{tabular}{|c|c|c|c|c|c|c|c|c|c|c|}
\hline \multirow[b]{2}{*}{ Malaysia } & 2003 & Obtain a local market & 32 & $15.9 \%$ & 45 & $22.4 \%$ & 124 & $61.7 \%$ & 201 & $100 \%$ \\
\hline & 2009 & $\begin{array}{c}\text { Establishing } \\
\text { overseas/production }\end{array}$ & 16 & $17.4 \%$ & 16 & $17.4 \%$ & 60 & $65.2 \%$ & 92 & $100 \%$ \\
\hline \multirow{2}{*}{ Philippines } & 2003 & $\begin{array}{c}\text { Establishing } \\
\text { overseas/production }\end{array}$ & 22 & $18.6 \%$ & 20 & $16.9 \%$ & 76 & $64.4 \%$ & 118 & $100 \%$ \\
\hline & 2009 & $\begin{array}{c}\text { Establishing } \\
\text { overseas/production }\end{array}$ & 20 & $21.5 \%$ & 38 & $40.9 \%$ & 35 & $37.6 \%$ & 93 & $100 \%$ \\
\hline \multirow[b]{2}{*}{ Indonesia } & 2003 & Obtain a local market & 52 & $26.3 \%$ & 45 & $22.7 \%$ & 101 & $51 \%$ & 198 & $100 \%$ \\
\hline & 2009 & $\begin{array}{c}\text { Establishing } \\
\text { overseas/production }\end{array}$ & 12 & $11.9 \%$ & 27 & $26.7 \%$ & 62 & $61.4 \%$ & 101 & $100 \%$ \\
\hline \multicolumn{11}{|l|}{ South Asia } \\
\hline \multirow[b]{2}{*}{ India } & 2003 & Obtain a local market & 7 & $29.2 \%$ & 5 & $20.8 \%$ & 12 & $50 \%$ & 24 & $100 \%$ \\
\hline & 2009 & $\begin{array}{c}\text { Establishing } \\
\text { overseas/production }\end{array}$ & 10 & $34.5 \%$ & 7 & $24.1 \%$ & 12 & $41.4 \%$ & 29 & $100 \%$ \\
\hline \multirow{2}{*}{ Bangladesh } & 2003 & Obtain labour & 0 & $0 \%$ & 3 & $42.9 \%$ & 4 & $57.1 \%$ & 7 & $100 \%$ \\
\hline & 2009 & Natural resources & 0 & $0 \%$ & 0 & $0 \%$ & 1 & $100 \%$ & 1 & $100 \%$ \\
\hline \multirow[t]{2}{*}{ Sri Lanka } & 2003 & Obtain labour & 1 & $14.3 \%$ & 0 & $0 \%$ & 6 & $85.7 \%$ & 7 & $100 \%$ \\
\hline & 2009 & $\begin{array}{c}\text { Establishing } \\
\text { overseas/production }\end{array}$ & 0 & $0 \%$ & 0 & $0 \%$ & 4 & $100 \%$ & 4 & $100 \%$ \\
\hline \multirow[t]{2}{*}{$\begin{array}{l}\text { Saudi } \\
\text { Arabia }\end{array}$} & 2003 & $\begin{array}{c}\text { Establishing } \\
\text { overseas/production }\end{array}$ & 0 & $0 \%$ & 0 & $0 \%$ & 5 & $100 \%$ & 5 & $100 \%$ \\
\hline & 2009 & Obtain labour & 0 & $0 \%$ & 0 & $0 \%$ & 1 & $100 \%$ & 1 & $100 \%$ \\
\hline
\end{tabular}

West

Europe

\begin{tabular}{|c|c|c|c|c|c|c|c|c|c|c|}
\hline & 2003 & Obtain a local market & 42 & $38.9 \%$ & 29 & $26.9 \%$ & 37 & $34.3 \%$ & 108 & $100 \%$ \\
\hline UK & 2009 & $\begin{array}{l}\text { Establish overseas } \\
\text { distribution }\end{array}$ & 1 & $1.7 \%$ & 12 & $20.7 \%$ & 45 & $77.6 \%$ & 58 & $100 \%$ \\
\hline \multirow{3}{*}{ Portugal } & 2003 & Obtain labour & 0 & $0 \%$ & 0 & $0 \%$ & 2 & $100 \%$ & 2 & $100 \%$ \\
\hline & 2009 & Information gathering & 2 & $12.5 \%$ & 7 & $29.2 \%$ & 14 & $58.3 \%$ & 24 & $100 \%$ \\
\hline & 2003 & Obtain a local market & 6 & $23.1 \%$ & 5 & $19.2 \%$ & 15 & $57.7 \%$ & 26 & $100 \%$ \\
\hline \multirow[t]{2}{*}{ Belgium } & 2009 & $\begin{array}{l}\text { Establish overseas } \\
\text { distribution }\end{array}$ & 5 & $33.3 \%$ & 5 & $33.3 \%$ & 5 & $33.3 \%$ & 15 & $100 \%$ \\
\hline & 2003 & Obtain a local market & 11 & $30.6 \%$ & 13 & $36.1 \%$ & 12 & $33.3 \%$ & 36 & $100 \%$ \\
\hline \multirow[t]{2}{*}{ France } & 2009 & $\begin{array}{c}\text { Establishing } \\
\text { overseas/production }\end{array}$ & 1 & $4.8 \%$ & 7 & $33.3 \%$ & 13 & $61.9 \%$ & 21 & $100 \%$ \\
\hline & 2003 & Obtain a local market & 3 & $3.7 \%$ & 32 & $39.5 \%$ & 46 & $56.8 \%$ & 81 & $100 \%$ \\
\hline Germany & 2009 & $\begin{array}{l}\text { Establish overseas } \\
\text { distribution }\end{array}$ & 13 & $25.5 \%$ & 16 & $31.4 \%$ & 22 & $43.1 \%$ & 51 & $100 \%$ \\
\hline \multirow{2}{*}{$\begin{array}{l}\text { Switzerlan } \\
\text { d }\end{array}$} & 2003 & $\begin{array}{l}\text { Establish overseas } \\
\text { distribution }\end{array}$ & 0 & $0 \%$ & 0 & $0 \%$ & 3 & $100 \%$ & 3 & $100 \%$ \\
\hline & 2009 & $\begin{array}{l}\text { Establish overseas } \\
\text { distribution }\end{array}$ & 0 & $0 \%$ & 0 & $0 \%$ & 3 & $100 \%$ & 3 & $100 \%$ \\
\hline \multicolumn{11}{|l|}{$\begin{array}{l}\text { South } \\
\text { Europe }\end{array}$} \\
\hline \multirow[b]{2}{*}{ Spain } & 2003 & Obtain a local market & 0 & $0 \%$ & 2 & $13.3 \%$ & 13 & $86.7 \%$ & 15 & $100 \%$ \\
\hline & 2009 & $\begin{array}{c}\text { Establishing } \\
\text { overseas/production }\end{array}$ & 1 & $14.3 \%$ & 1 & $14.3 \%$ & 5 & $71.4 \%$ & 7 & $100 \%$ \\
\hline
\end{tabular}




\begin{tabular}{ccccccccccc}
\hline \multirow{3}{*}{ Italy } & 2003 & Obtain a local market & 2 & $18.2 \%$ & 0 & $0 \%$ & 9 & $81.8 \%$ & 11 & $100 \%$ \\
& 2009 & Obtain a local market & 5 & $33.3 \%$ & 3 & $20 \%$ & 7 & $46.7 \%$ & 15 & $100 \%$ \\
Turkey & 2003 & Obtain labour & 3 & $75 \%$ & 0 & $0 \%$ & 1 & $25 \%$ & 4 & $100 \%$ \\
& 2009 & $\begin{array}{c}\text { Company with } \\
\text { dealer/buyer seller }\end{array}$ & 0 & $0 \%$ & 0 & $0 \%$ & 1 & $100 \%$ & 1 & $100 \%$
\end{tabular}

East

Central

\begin{tabular}{|c|c|c|c|c|c|c|c|c|c|c|}
\hline & 2003 & Obtain labour & 2 & $100 \%$ & 0 & $0 \%$ & 0 & $0 \%$ & 2 & $100 \%$ \\
\hline Hungary & 2009 & $\begin{array}{c}\text { Establishing } \\
\text { overseas/production }\end{array}$ & 5 & $45.5 \%$ & 1 & $9.1 \%$ & 5 & $45.5 \%$ & 11 & $100 \%$ \\
\hline \multirow{2}{*}{ Russia } & 2003 & Export to third country & 3 & $30 \%$ & 0 & $0 \%$ & 7 & $70 \%$ & 10 & $100 \%$ \\
\hline & 2009 & Obtain a local market & 2 & $50 \%$ & 0 & $0 \%$ & 2 & $50 \%$ & 4 & $100 \%$ \\
\hline Czech & 2003 & Obtain a local market & 1 & $33.3 \%$ & 0 & $0 \%$ & 2 & $66.7 \%$ & 3 & $100 \%$ \\
\hline Republic & 2009 & $\begin{array}{c}\text { Establishing } \\
\text { overseas/production }\end{array}$ & 0 & $0 \%$ & 6 & $50 \%$ & 6 & $50 \%$ & 12 & $100 \%$ \\
\hline
\end{tabular}

North

America

\begin{tabular}{|c|c|c|c|c|c|c|c|c|c|c|}
\hline \multirow[b]{2}{*}{ Canada } & 2003 & Obtain a local market & 5 & $10.2 \%$ & 15 & $11.5 \%$ & 29 & $27.5 \%$ & 49 & $100 \%$ \\
\hline & 2009 & $\begin{array}{l}\text { Establish overseas } \\
\text { distribution }\end{array}$ & 12 & $44.4 \%$ & 2 & $7.4 \%$ & 13 & $48.1 \%$ & 27 & $100 \%$ \\
\hline & 2003 & Obtain a local market & 169 & $27.8 \%$ & 186 & $30.6 \%$ & 253 & $41.6 \%$ & 608 & $100 \%$ \\
\hline & 2009 & Obtain a local market & 72 & $20.1 \%$ & 123 & $34.3 \%$ & 164 & $45.7 \%$ & 359 & $100 \%$ \\
\hline
\end{tabular}

Middle

South

2003

Mexico

2009

2003

Panama

2009

Chile

2003

2009

2003

Brazil

2009

2003

Argentina 2009

2003

Panama

2009
Establishing overseas/production

Establishing overseas/production

Favoured treatment by local government

Miscellaneous

Natural resources

Natural resources

Obtain a local market

Natural resources

Obtain a local market

Obtain a local market

Favoured treatment by local government

Miscellaneous
$3 \quad 18.8 \%$

$3 \quad 33.3 \%$

$15 \quad 36.6 \%$

23

$56.1 \%$

$41 \quad 100 \%$

$0 \quad 0 \%$

$0 \quad 0 \%$

$0 \quad 0 \%$

$1 \quad 100 \%$

100

$\begin{array}{llllll}0 & 3 & 100 \% & 0 & 0 \% & 3\end{array} \%$

Africa $\begin{array}{cccccccc}0 & 0 \% & 3 & 60 \% & 2 & 40 \% & 5 & \begin{array}{c}100 \\ \%\end{array}\end{array}$

$\begin{array}{llllllll}2 & 40 \% & 0 & 0 \% & 3 & 60 \% & 5 & 100 \%\end{array}$ $\begin{array}{llllllll}12 & 25.4 \% & 13 & 26.5 \% & 24 & 49 \% & 49 & 100 \%\end{array}$

$\begin{array}{llllllll}4 & 19 \% & 10 & 47.6 \% & 7 & 33.3 \% & 21 & 100 \%\end{array}$

$\begin{array}{llllllll}2 & 66.7 \% & 1 & 33.3 \% & 0 & 0 \% & 3 & 100 \%\end{array}$

$\begin{array}{llllllll}1 & 100 \% & 0 & 0 \% & 0 & 0 \% & 1 & 100 \%\end{array}$

$\begin{array}{llllllll}0 & 0 \% & 0 & 0 \% & 1 & 100 \% & 1 & 100 \%\end{array}$

$\begin{array}{llllllll}0 & 0 \% & 3 & 100 \% & 0 & 0 \% & 3 & 100 \%\end{array}$ 


\begin{tabular}{|c|c|c|c|c|c|c|c|c|c|c|}
\hline & 2003 & Natural resources & 0 & $0 \%$ & 0 & $0 \%$ & 4 & $100 \%$ & 4 & $100 \%$ \\
\hline Nigeria & 2009 & Natural resources & 0 & $0 \%$ & 0 & $0 \%$ & 4 & $100 \%$ & 4 & $100 \%$ \\
\hline \multicolumn{11}{|l|}{ Oceania } \\
\hline & 2003 & Obtain a local market & 5 & $12.2 \%$ & 22 & $53.7 \%$ & 14 & $34.1 \%$ & 41 & $100 \%$ \\
\hline Australia & 2009 & $\begin{array}{l}\text { Establish overseas } \\
\text { distribution }\end{array}$ & 4 & $11.4 \%$ & 10 & $28.6 \%$ & 21 & $60 \%$ & 35 & $100 \%$ \\
\hline \multirow{2}{*}{$\begin{array}{l}\text { New } \\
\text { Zealand }\end{array}$} & 2003 & $\begin{array}{l}\text { Establish overseas } \\
\text { distribution }\end{array}$ & 2 & $33.3 \%$ & 0 & $0 \%$ & 4 & $66.7 \%$ & 6 & $100 \%$ \\
\hline & 2009 & $\begin{array}{l}\text { Establish overseas } \\
\text { distribution }\end{array}$ & 0 & $0 \%$ & 2 & $50 \%$ & 2 & $50 \%$ & 4 & $100 \%$ \\
\hline
\end{tabular}

\section{Conclusion, Implications, and Limitations}

In this research, we are interested in measuring the investment objectives of Japanese MNCs and their subsidiary's performance. Based on the locational aspect, China, America, and Thailand were the most favourable countries of Japanese MNCs. With rapid economic growth in Asia, intra-regional trade and FDI by Japanese MNCs are also increasing. Therefore, East Asia indicates the highest number of Japanese MNCs outward FDI, followed by the Southeast Asian region in 2003 and 2009. Bilateral and regional approaches for Free Trade Agreements (FTA) are currently being pursued to further improve the competitiveness of countries in the region. This will possibly influence the high investment of Japanese MNCs in Asian countries, due to an increasing number of Japanese companies taking advantage of FTA's, or at least, considering the possibilities of doing so. Based on the JETRO survey in 2010, companies taking advantage of major FTA's enacted by Japan (with Malaysia, Thailand, Philippines, Indonesia, Vietnam, Mexico, Chile, and Switzerland) have reached $35.2 \%$ of all surveyed companies engaged in trade with FTA parties (i.e., 673 companies). The Japan-Thailand Economic Partnership Agreement (29.1\%) achieved the second highest ranking in utilising rate by FTA for export (JETRO, 2011). Furthermore, the percentage of tariff-free products in these FTA's increased greatly. In ASEAN countries, a Free Trade Area (AFTA) was established, with ASEAN regional tariffs eliminated in 99\% of all products subject to trade, from January 2010. This means that the trade of goods within the ASEAN region is almost entirely tariff-free, which boosts the FTA utilisation value.

Apart from locational aspects, other determinant factors or investment objectives of outflow FDI from Japan have also captured the attention of international business scholars. Locational factors, such as subsidiary region and countries also have a significant influence on Japanese MNCs investment objectives. Generally, majority Asian nations consist of developing countries with huge market potentials, such as China and other ASEAN countries. Empirical results show that Japanese MNCs investing into the Asian region prefer to choose 'obtaining a local market' during the early stages of entering into host countries, which they revise to new investment objectives after a certain period of maintaining the firm's profitability. These findings support the first hypothesis, which stated that the locational factor influences Japanese MNCs investment motives in a host country.

Even though each county has different investment objectives, our findings generally considered that 'obtaining a local market' was the main investment objective for Japanese MNCs in 2003. Six years later, most Japanese MNCs changed their investment objectives, and in 2009, 'establishing an overseas production network' became the main investment motive. This alteration importantly suited the need to fulfil their current business strategy. Statistical tests showed that companies using the 'obtain a local market' investment objective had a significant breakeven performance in 2009, instead of a performance 'gain' in 2003. Therefore, the alteration of this investment objective was a crucial decision by Japanese MNCs to ensure that their subsidiaries were in a good performance condition to survive in their host countries.

Finally, the statistical results of this study also suggest that locational factors and investment objectives also influence subsidiary performance (as shown in Table 7). Japan MNCs subsidiaries in the Asian region showed a consistent performance 'gain' in 2003 and 2009; except for the Philippines, with a 'slight decrease' to 'breakeven' performance in 2009. In Western Europe, the 'obtain a local market' investment objective was not very successful in 2003 for the UK and France. Therefore, Japanese MNCs investors in those countries changed their motive of investment to 'establishing an overseas production network' in 2009, and achieved a better performance in that particular year. In addition, the 'obtain a local market' investment strategy was doing well 
for Japanese subsidiaries in two developed countries; namely Italy and the US. Therefore, they kept this investment strategy in 2003 and 2009, to maintain the performance 'gain' for their subsidiaries in these two countries. Based on the Investment Development Path (IDP) paradigm, our findings show that most Japanese MNCs outward investments were at Stage 3, where the level of FDI in countries with rising inward and outward FDI and primary motive of FDI was for market seeking. Therefore, the second and third hypotheses are supported, where Japanese MNCs investment objectives and locational factors significantly affect subsidiary performance in the host countries.

From the findings obtained in this research, it is possible to infer several general recommendations and implication for academics and decision-makers, who are responsible for defining locations and types of country, before entering a host country. As for academicians, this paper contributes to the initial field of research that clearly focuses on testing the extent to which the theoretical argument is present in the IDP approach are valid for countries positioned at different stages along the path. Conducting new empirical studies will help progress in the identification of the main investment objectives and location factors with their performance. Clearly, this effort would lead to a better understanding of the different motivations, and hence, location factors behind the FDI carried out by MNCs.

Moreover, it is widely recognized that the selection of a host country for locating FDI is often one of the most important decisions that managers of firms currently have to make. Within this context, it is assumed that many location-related variables may have a crucial influence on global competitiveness, and hence, the probability of the long-term survival of numerous firms. Therefore, this study reveals that managers' knowledge of development stage of the host country can be useful for achieving the objectives set out by their firms.

To conclude, we note certain limitations in this paper and make suggestions for future research necessary to overcome them. The first limitation was data reliability and availability. Even though we tried to consider many variables from the data of parent companies in measuring the performance of subsidiaries, this does not mean that we were able to capture all of the data variables. This implies that it is still necessary to use other variables, such as the financial data of parent and subsidiary companies, which may affect the success of subsidiaries in foreign countries. It would also be interesting to combine and analyse actual financial data with self-assessment questionnaires completed by Japanese subsidiaries globally. Furthermore, only Japanese companies took part in this research. Therefore, with the data available to us, our general findings were confined to Japanese firms only. Future research should look into this aspect.

\section{Acknowledgments}

This study supported by JSPS KAKENHI Grant Number 21530410, 24530500 and Malaysia Ministry of Higher Education (MOHE).

The authors wish to thank Mr. Fazli Md Sam graduate student in Graduate School of Business Administration, Aichi University, and Mr. Mohamed Hafiz Md. Isa from Nagoya University, Japan for their comments and helpful guide.

\section{References}

Agarwal, S. (1994). Social-cultural distance and the choice of joint venture: a contingency perspective. Journal of International Marketing, 2(2), 63-80.

Aharoni, Y. (1966). The Foreign Investment Decision Process. Boston, MA: Haevard University.

Anderson, E., \& Gatignon, H. (1986). Modes of foreign entry: a transaction cost analysis and propositions. Journal of International Business Study, 17(3), 1-26. http://dx.doi.org/10.1057/palgrave.jibs.8490432

Anderson, U., \& Forsgren, M. (2000). In search of centre of excellence: Network embeddedness and subsidiary roles in multinational corporations. Management International Review, 40(4), 329-350.

Anderson, U., \& Forsgren, M. (2000). In search of centre of excellence: Network embeddedness and subsidiary roles in multinational corporations. Management International Review, 40(4), 329-350. Retrieved from http://www.jstor.org/stable/40836151

Asiedu, E. (2006). Foreign Direct Investment in Africa: The Role of Natural Resources, Market Size, Government Policy, Institutions and Political Instability. The World Economy, 29(1), 63-77. http://dx.doi.org/10.1111/j.1467-9701.2006.00758.x

Bandelj, N. (2002). Embedded economies: social relations as determinants of foreign direct investment in Central and Eastern Europe. Social Forces, 8(2), 409-444. http://dx.doi.org/10.1353/sof.2003.0001 
Bhinda, N., Griffith-Jones, S., \& Martin, M. (1999). Foreign Direct Investment. In N. Bhinda, J. Leape, S. Griffith-Jones, \& M. Martin, Private Capital Flows to Africa: Perception and Reality (pp. 49-178). The Hague: Fondad.

Bitzenis, A., Marangos, J., \& Nuskova, V. (2007). Motives for foreign direct investment in the manufacturing sector in FYR Macedonia. Post-Communist Economies, 19(4), 505-527. http://dx.doi.org/10.1080/14631370701680337

Brown, P. R., Soybel, V. E., \& Stickney, C. P. (1994). Comparing U.S. and Japanese corporate level operating performance using financial statement data. Strategic Management Journal, 15(1), 75-83. http://dx.doi.org/10.1002/smj.4250150106

Buckley, P., \& Casson, M. (1976). The Future of the Multinational Enterprises. Macmillan, London.

Buckley, P., \& Casson, M. (1998). Analyzing foreign market entry strategies: extending the internationalization approach. Journal of International Business Studies, 29(3), 599-607. Retrieved from http://www.jstor.org/stable/155524

Cespedes, C. V., \& Hoshino, Y. (2001). Effects of ownership and internalization advantages on performance: The case of Japanese subsidiaries in the United State and Latin America. Review of Pacific Basin Financial Markets and Policies, 4(1), 69-94. http://dx.doi.org/10.1142/S0219091501000346

Cheng, L., \& Kwan, Y. (2000). What are the determinants of the location of foreign direct investment? The Chinese experience. Journal of International Economics, 51, 379-400. http://dx.doi.org/10.1016/S0022-1996(99)00032-X

Dar, H., Presley, A., Malik, J., \& Shahid, H. (2004). Determinants of FDI inflows to Pakistan (1970-2002). Economics Research Paper, No. 04-20. Retrieved from http://hdl.handle.net/2134/32

Davidson, W. (1980). The location of foreign direct investment activity: country characteristics and experience $\begin{array}{lllll}\text { effects. Journal of International Business } & \text { Studies, }\end{array}$ http://dx.doi.org/10.1057/palgrave.jibs. 8490602

Davidson, W., \& McFetridge, D. (1985). Key characteristics in the choice of international technology transfer mode. Journal of International Business Studies, 16(2), 5-21. http://dx.doi.org/10.1057/palgrave.jibs.8490448

Driffield, N., \& Love, J. H. (2007). Linking FDI motivation and host economy productivity effects: Conceptual and empirical analysis. Journal of International Business Studies, 38(3), 460-473. http://dx.doi.org/10.1057/palgrave.jibs. 8400268

Dunning, J. H. (1988). The eclectic paradigm of international production: a restatement and some possible extensions. Journal of International Business Studies, 19(1), 1-31. http://dx.doi.org/10.1057/palgrave.jibs. 8490372

Dunning, J. H. (1993). Multinational Enterprises and the Global Economy. New York: Addison-Wiley.

Dunning, J. H. (2000). The eclectic paradigm as an envelope for economic and business theories of MNE activity. International Business Review, 9(2), 163-190. http://dx.doi.org/10.1016/S0969-5931(99)00035-9

Eicher, T., \& Kang, J. W. (2005). Trade, foreign direct investment or acquisition: Optimal entry modes for $\begin{array}{llll}\text { multinationals. Journal of Development Economics, } & \text { 77(1), }\end{array}$ http://dx.doi.org/10.1016/j.jdeveco.2004.03.007

Froot, K. A., \& Stein, J. C. (1991). Exchange rate and foreign direct investment: an imperfect capital markets approach. The Quarterly Journal of Economics, 106(4), 1191-217. http://dx.doi.org/10.2307/2937961

Galan, J. I., González-Benito, J., \& Zuñga-Vincente, J. A. (2007). Factors determining the location decisions of Spanish MNEs: An analysis based on the investment development path. Journal of International Business Studies, 38(6), 975-997. http://dx.doi.org/10.1057/palgrave.jibs.8400304

Geringer, J., \& Herbert, L. (1991). Measuring performance of international joint ventures. Journal of International Business Studies, 22(2), 249-263. http://dx.doi.org/10.1057/palgrave.jibs.8490302

Jackson, J. K. (2012). Foreign direct investment in the United States: An economic analysis. Specialist in International Trade and Finance. United States: Congressional Research Service. Retrieved from http://digitalcommons.ilr.cornell.edu/cgi/viewcontent.cgi?article=1924\&context=key_workplace

JETRO. (2011). 2011 JETRO Global Trade and Investment Report : International Business as a Catalyst for 
Japan's Reconstruction. Retrieved from Japan External Trade Organization: http://www.jetro.go.jp/en/reports/white_paper/trade_invest_2011.pdf

Kinoshita, Y. (1998). Firm Size and Determinants of Foreign Direct Investment. Prague, Republic Czech. Retrieved from http://zunia.org/uploads/media/knowledge/Wp1351.pdf

Kobrin, S. (1976). The environmental determinants of foreign direct manufacturing investment: an ex post empirical analysis. Journal of International Business Studies, 8(2), 29-42. http://dx.doi.org/10.1057/palgrave.jibs.8490699

Loree, D., \& Guisinger, S. (1995). Policy and non-policy determinants of US equity foreign direct investment. Journal of International Business Studies 26(2), 281-299. http://dx.doi.org/10.1057/palgrave.jibs.8490174

Makino, S., \& Beamish, P. W. (1998). Local ownership restrictions, entry mode choice and FDI performance: Japanese overseas subsidiaries in Asia. Asia Pacific. Journal of Management, 15(2), 119-136. http://dx.doi.org/10.1023/A:1015481312926

Makino, S., \& Delios, A. (1996). Local knowledge transfer and performance: Implication for alliance formation in Asia. Journal International Business Study, 27(5), 905-27. http://dx.doi.org/10.1057/palgrave.jibs.8490156

Nakamura, S.-y., \& Oyama, T. (1998, November). The determinants of foreign direct investment from Japan and United States to east Asian countries, and the linkage between FDI and trade. Tokyo, Tokyo, Japan. Retrieved from http://www.boj.or.jp/en/research/wps_rev/wps_1998/cwp98e11.htm/

Narula, R. (1996). Multinational Investment and Economic Structure. London: Routledge.

Narula, R., \& Dunning, J. H. (2000). Industrial development, globalization and multinational enterprises: new realities for developing countries. Oxford Development Studies, 28(2), 141-67. Retrieved from http://eco.ieu.edu.tr/courses/econ322/lecture/narula\&dunning_2000.pdf

Nicholas, S. (1987). Empirical test of the transaction cost model: The evolution of the Pre-1939 British manufacturing multinational. Business and Economic History, 16(2), 133-145. Retrieved from http://www.thebhc.org/publications/BEHprint/v016/p0133-p0146.pdf

Ohlin, B. (1933). Interregional and International Trade. Cambridge: Harvard University.

Ok, S. T. (2004). What drives foreign direct investment into emerging markets?: evidence from Turkey. Emerging Markets Finance and Trade, 40(4), 101-114.

Resmini, L. (2000). The determinants of foreign direct investment in the CEECs: new evidence from sectoral patterns. Economics of Transition, 8(3), 665-689. http://dx.doi.org/10.1111/1468-0351.00060

Rugman, A. (1987). Multinationals and trade in services: A transaction cost approach. Review of World Economics (Weltwirtschaftliches Archiv), 123(4), 651-667. http://dx.doi.org/10.1007/BF02708572

Saayman, M., \& Snyman, J. A. (2005). Entrepreneurship: tourism style. Potchefstroom: Leisure C.

Sazanami, Y. (1992). Determinants of Japanese foreign direct investment: Locational attractiveness of European countries to Japanese multinationals. Revue économique, (43), 661-669.

Seetanah, B., \& Rojid, S. (2011). The determinants of FDI in Mauritius: a dynamic time series investigation. African Journal of Economic and Management Studies, 2(1), 24-41. http://dx.doi.org/10.1108/20400701111110759

Snyman, J. A., \& Saayman, M. (2009). Key factors influencing foreign direct investment in the tourism industry in South Africa. Tourism Review, 64(3), 49-58. http://dx.doi.org/10.1108/16605370910988827

Tahir, R., \& Larimo, J. (2006). Strategic motivations of Finnish FDI s in Asian countries. Cross Cultural Management: An International Journal, 13(3), 244-256. http://dx.doi.org/10.1108/13527600610683381

Toyo Keizai Inc. (2005-2009). Japan Company Hanbook. Tokyo: Toyo Keizai Inc.

Urata, S., \& Kawai, H. (2000). The determinants of the location of foreign direct investment by Japanese small and medium-sized enterprises. Small Business Economics, 15(2), 79-103. http://dx.doi.org/10.1023/A:1008173912813

Wheeler, D., \& Mody, A. (1992). International Investment Location Decisions: The Case of U.S. Firms'. Journal of International Economics, 33, 57-76. http://dx.doi.org/10.1016/0022-1996(92)90050-T 